\title{
Material / Blackness: Race and Its Material Reconstructions on the Seventeenth-Century English Stage
}

\begin{abstract}
Examining William Shakespeare's Titus Andronicus, William Heminge's The Fatal Contract, and Elkanah Settle's Love and Revenge, this article argues that the seventeenth-century English stage imagines blackness as fluid and transferable because of the materials used in its production. These cosmetics are imagined as being potentially moveable from one surface to another. The article considers the intersection between the materials used to recreate blackness and its semiotic values, focusing on the relationship between black bodies and female bodies. It argues that the materials used in the recreation of these bodies inform and are informed by the panoply of discourses surrounding them.
\end{abstract}

In an oft-cited letter about the January 1605 performance of The Masque of Blackness, courtier Dudley Carleton records his horror at the potential for the materials that recreated blackness to slide from the bodies after application. ${ }^{1}$ Ninety-three years later, in 1698, Barton Booth's performance of Othello faced similar problems with the materials that recreated blackness; Booth smeared the cosmetics, lost the mask, and eventually resorted to lampblack to blacken his face. These moments of imagined failure in 1605 and actual failure in 1698 make visible the material recreation of blackness on the stage throughout the 1600s. Bemoaning that his daughter has 'shunned / the wealthy curled darlings of [Venice]' out of preference for 'the sooty bosom / of such a thing as [Othello]' (1.2.68-70), ${ }^{2}$ Brabantio makes visible the body of Othello to the audience through the materials used to reconstruct the black body in performance. Othello's racial identity is couched in material terms, and uses a material which signals transferability and the potential movement of pigment. The visibility of materials in the recreation of skin colour as a racial differentiator flickers in and out of early modern dramatic texts, but has a significant impact on representations of blackness in

Morwenna Carr (morwenna.carr@roehampton.ac.uk) is a research fellow at the University of Roehampton. 
particular. Using Shakespeare's Titus Andronicus (1588), William Heminges's The Fatal Contract (1653), and Elkanah Settle's adaptation of that play, Love and Revenge (1675), this article argues that the material conditions of blackness on the stage intertwine with ideas about race, otherness, vulnerability, and contagion. The material conditions of the stage inform the language used by playwrights to recreate blackness in the mind of the audience, facilitating the location of a panoply of racial fears in the bodies of racial others. The performance conditions imposed by the material used in the recreation of blackness on the seventeenthcentury English stage have, therefore, had a substantial and long-lasting impact on representations of blackness and race. Using three plays that foreground in both text and action the materials that recreate blackness on the early modern stage, I consider seventeenth-century drama's 'rhetorical miscegenation' through the lens of the materials that reconstruct racial otherness on the professional stage, scrutinizing the materiality of staged 'blackness' in relation to the language that recreates it in relationship to female bodies.

The languages of blackness have been the focus of considerable critical attention, principally in relation to Othello (1603). Karen Newman, for example, identifies what she terms 'rhetorical miscegenation' in Othello; the oppositions of 'black' and 'white', she argues, are a significant part of the discourse of miscegenation which runs throughout the play's action, culture, character representation, and language. ${ }^{3}$ Ian Smith's work also emphasizes the importance of language in the recreation of English nationhood and 'whiteness'; language is a 'cultural sign through which race relations in England can be traced' and in which those who identify as English' and 'white' situate themselves inside speech constructed as 'eloquent' and 'civilised'. Smith, too, considers Othello, offering a reading in which 'Shakespeare challenges the reading of otherness as a paranoid displacement of anxieties and exposes as fake the supposed mastery and superiority of the European self over the alien' by making Iago the site of black stereotypes and racialized behavioural codes. ${ }^{4}$ As I will demonstrate, however, the rhetoric used to describe blackness can display an awareness of the perceived acute dangers of blackness mediated through a metatheatrical awareness of the conditions in which the early modern stage produces blackness. The material reality of 'blackness' undermines the 'systematic inversion' of racial codes that Smith identifies in Othello, although it ultimately contributes to the play's 'questioning of the entire Venetian and English racial structure as stable, natural, and entirely discrete'. 


\section{The Materials of Cosmetic Blackness}

When Carleton penned his infamous letter about the courtly entertainment Anna of Denmark performed in 1605, he recorded the cosmetic blacking up of her body: 'instead of vizards, their Faces and Arms up to the Elbows were painted black, which was a disguise sufficient for they were hard to be known'. These cosmetics were often not complex preparations, although Nicholas Hilliard's The Arte of Limning includes a recipe for a pigment made from burnt ivory and gum:

Let it settle a whole afternoon, and pour from it the uppermost, which is but the gum and foulness, good to put among ink. The rest let dry, and keep it in a paper or box and use it aforesaid with soft grinding of it again. ${ }^{6}$

Hilliard's recipe implies a hierarchy of black paint: the pigment which is kept and used in drawing and painting, and the 'gum and foulness' fit only to be utilised in the production of ink. The professional theatre's pigments were cheaper and more accessible than burnt ivory, made of charcoal, lampblack, coal, and cork added to bases of animal fats, grease, tallow, water, and egg white. These bases were the same as those used in the production of non-theatrical cosmetics and, as Meg Twycross and Sarah Carpenter note, were made of 'easily available domestic materials' 7 These materials, they argue, created a mask-like cosmetic effect of monotone blackness which would have been both unrealistic and flattening. These materials could be built up in layers on the surfaces of the body, however, deepened by repeated applications and buffed into shining, so that the planes of the face could be recreated in differing depths of colour even with the most rudimentary of material preparations. With access to other cosmetics (such as those used by boy actors in the recreation of 'female' bodies, including whitening fucuses and red stains ${ }^{8}$ ), and some skill, these materials need not have 'blank[ed] out the features' of the performer. ${ }^{9}$

These materials presented Ben Jonson with a dilemma: although in his text for the Masque of Blackness the beautifying rays of James I's royal glory are supposedly strong enough to 'blanch an AETHIOPE and revive a Cor's' (2.255), the use of cosmetics complicated matters and the masque subsequently ends not with the revelation of 'white' female bodies but with a promise that, at next year's masque, they would have metamorphosed from 'black' to 'white'. Carleton's letters betray a deep concern about the impact that this cosmetic blackening could have on Britain's international standing, particularly in relationship to Spain. Most worryingly, the Spanish ambassador was present as a guest of honour, and, 
as he danced with Anna, he 'forgot not to kiss her Hand, though there was a danger it would have left a mark on his Lips'. No record exists of any actual bodily transfer happening, but Carleton clearly anticipates one. Not only has James failed to remake blackness as whiteness, but bystanders imagine his wife's 'blackness' as having the power to spread.

At the other end of the century, in 1698, the cosmetics used to blacken the actor Barton Booth did just that during a run of Othello on the professional stage; a problem continued of both real and imagined potential transferability in relation to blackening cosmetics throughout the 1600 s, and the same problems that had dominated earlier discourses of 'black' bodily materiality in the theatre dogged performances of Othello:

It being very warm Weather, in his last scene of the Play, as [Booth] waited to go on, he inadvertently wip'd his Face, that when he enter'd he had the Appearance of a Chimney-Sweep (his own Words). At his Entrance, he was surpriz'd at the Variety of Noises he heard in the Audience (for he know not what he had done) that a little confounded him till he receiv'd an extraordinary Clap of Applause, which settl'd his Mind. The Play was desir'd for the next Night of Acting, when an Actress fitted a Crape to his Face with an Opening proper for the Mouth, and shap'd in form for the Nose; but in the first Scene, one Part of the Crape slipp'd off. And 'Zounds!' said he, (he was a little apt to swear) 'I look'd like a Magpie! When I came off they lampblack'd me for the Rest of the Night, that I was flead before it could be got off again'. ${ }^{10}$

Booth uses three distinct methods of blackening here: first, he tries an undisclosed paint, which is unstable and subsequently partially removed; second, he tries a crepe mask made from a number of different pieces, which slips during performance; and finally, he resorts to lampblack, a by-product of the incomplete combustion of coal, tar, or fat. Lampblack as a pigment is highly stable and adhesive, but its benefits during performance are outweighed by its disadvantages after the performance - Booth describes the experience of its removal as akin to being flayed. While a difference of ninety-three years separates Anna's and Booth's performances as racial others, both accounts demonstrate similar performance problems. The cosmetics and costumes actors used in the recreation of 'black' bodies on stage throughout the seventeenth century were both physically and conceptually unstable, prone to movement from one surface to another. ${ }^{11}$

These material conditions of performing blackness, on a stage on which whiteness is represented as normative, are visible in a number of seventeenth-century 
play-texts after the 'coal-black' (4.2.116-18) that Aaron uses in Titus Andronicus (1588), the earliest of the plays considered in this article. ${ }^{12}$ Jonson also uses soot or coal in connection with black skin: the boy who is to play Ganymede in Poetaster (1601) is told that he 'should have rub'd [his] faced, with whites of egges' to give him shining brows like those of 'our sooty brother' Vulcan (4.327). ${ }^{13}$ As I note above, in Othello (1603) Brabantio rails against Othello and his 'sooty bosom' (1.2.73), and in Gervase Markham's The Dumb Knight (1608) Phyloclyes declares that he would 'rather wed a sooty blackamore' than Mariana (3.1). ${ }^{14}$ Jonson also makes visible other skin transforming materials: in The Gypsies Metamorphosed (1621) he advocates that 'Wall-nuts and Hogges-grease [are] / better than Dogs grease' to 'change your Complexion' (Epilogue, 1120-3). ${ }^{15}$ In William Rowley's tragedy All's Lost by Lust (1618-20) Roderigo describes the army of Moors facing off against the Spanish as 'sooty as the inhabitants of hell' (1.1.33), while Jacinta uses the adjective 'sooty' in relation to their king, Mully Mumen (5.5.15). ${ }^{16}$ Later, The Strange Discovery (1640) by I.G. Gent figures Sisimehtres as a 'very sweet fac'd Gentleman, so sooty as the Divel himself' (1.1). ${ }^{17}$

The development of and changes to materials used in the recreation of blackness over the seventeenth century is the focus of work by Andrea R. Stevens and Dympna Callaghan. Whilst Stevens argues that cosmetics and paints had become the 'primary means for representing racial otherness' by the 1580 s, ${ }^{18}$ Callaghan has demonstrated a continuous use of lambskin wigs and other fabric prosthetics throughout the $1600 s .{ }^{19}$ Indeed, the most practical solution for theatres, given both economic and physical constraints, would have been a combination of cosmetic and prosthetic costuming. Fabric costumes, including wigs, stockings, and gloves, could be repeatedly used for different performances, and contributed to the net material assets of a company; companies on the move or financially constrained, on the other hand, could procure cosmetics easily and cheaply. However popular cosmetics were, players continued to use gloves extensively; this practice can be no surprise given the obvious potential for cosmetically blackened hands to damage costly clothing and costuming. ${ }^{20}$ Stevens points to the often contrary representation of paint and its relationship to the body, in which the use of cosmetics remakes bodily invulnerability through the preparations' refining properties, and yet can also contaminate and corrode susceptible bodies. ${ }^{21}$ Ian Smith's work further supports views regarding the continuation of costumes alongside cosmetic prosthetics: texts which note the use of cosmetics in the recreation of blackness register surprise at new theatrical techniques, and while the use of cosmetics became increasingly dominant in professional and courtly performances 
from the 1600s, Smith convincingly argues, 'textile techniques' remained in practice and continued to be part of 'audience memory'. 22

Awareness of the use of cosmetic techniques in the recreation of blackness is visible beyond the play-texts of the 1600s. The use of coal to blacken appears in The Merry Jests of Smug the Smith, for example, a tale written by Thomas Brewer printed in 1631 and reprinted in 1657. ${ }^{23}$ The text that records this incident of blackening ostensibly offers an account of Peter Fabell, the merry devil of Edmonton, although it is more concerned with the slapstick pranks around Smug the smith than with the magician. In one episode, Smug is plied with drink and eventually falls asleep, only to fall victim to the pranks of 'three or four mad consorts':

They got a good handful of small [coals] which they beat to powder, and ... put them into a dish of faire water. When they had Well-mingled (like right dawbing Painters) their Small-Coale powder, blacking, and Water together, and made a perfect Coale-black ... they sayd it on his face, which was a reasonable black before, not leaving so much white or red to be seen as a small pins-head will cover. When they had thus be blacked and [besmirched] him, with his Divels look, they left him snorting on the Porch-bench.

When Smug wakes up, unaware of his blackened face, he reels through the village and attracts a crowd of 'Boyes at playe' who follow him chanting 'Divel Divel' as he staggers home to his wife (D2r). When she attempts to show him his black face, Smug interprets the mirror image of himself as a devil and 'struck at it, and with one blow clattered the Glasse' (D3v). Fortunately, a second mirror is available to show him his visage once he has sobered up the next day:

when [he] saw, and knew well what he saw, he blusht; but the [j]est was it could not to be see[n], till his [v]izard was taken off with faire [water] and soape. (D3v)

Brewer's tale demonstrates the prevalent use of coal and soot to recreate blackness; cheaply and easily accessible even to drunken pranksters not reported as having any connection to theatres and their transformative techniques, coal and soot were easy ways to represent blackness on the early modern stage.

Like the other dramatic texts considered here, Brewer's tale presents the process of cosmetic blackening in front of an audience. This text represents the material reconstruction of skin colour as a moment of carnivalesque play, with the crowd of boys chanting and following the blackened Smug. After 'quaffing together', companions lead the drunken Smug 'out of the Ale-House into the Church-porch', lay 
him 'back upon a Bench', and, placing his head on a 'little Joynt-stoole' to ensure visibility, arrange the blacksmith as an effigy 'like [an] Image of Duke Humphrey, over his long ago consumed Carkas' (15-16). After being painted with the coal mixture and left exhibited on his bench, Smug reels home in front of a crowd. The reprinting of this text in 1657, during the closure of the theatres, connects these moments of social performance with the ostensibly banned professional stages. ${ }^{24}$ This mode of material blackness thus circumnavigates the closure of the professional theatres, connecting the text's readers with earlier performances and modes of material recreation. The overlap between blackface performance with earlier and contemporaneous forms of mumming, in particular, combines with the concern around the identification and policing of maskers and 'black' faces which Twycross and Carpenter argue is the focal point of anti-mumming legislation. ${ }^{25}$ Smug's failure to recognize himself in the mirror makes explicit societal concerns over the potential civic and social problems of anonymity; Smug, who fails even to recognize his own reflection, fulfils the mummers' goal of making themselves unrecognizable. His response to the reflection of his blackened face draws in another strand of the many dialogues surrounding racial identity and racism in this period as he interprets his black visage as a manifestation of the devil. When he later recognizes himself and the prank enacted on him, the tale points to yet another strand of racial discourse as the layer of soot obscures his responsive blush.

The material reality of recreating blackness intersects with each of these strands of dialogue. The materials used to recreate blackness connect it to the practice of mumming and disguise - both celebrating the laughter around making an insensible drunk unrecognizable and exposing the social and personal worry about failure to recognize and read. In turn, the application of soot renders Smug temporarily 'black', both exoticizing him and connecting him with devilry. In discourses that associate devilry and blackness, the use of soot as a material to recreate blackness is particularly interesting. Using soot not only leaves the 'devil' in question blackened but also connects that body to the fires which produce soot, and thereby to the biggest fire of the early modern imagination that of hell. Soot and coal render the person who has been crudely smeared with them unreadable; the application of these flat cosmetics renders the planes of the face stiff and without depth from reflections, thus obliterating both the features and delicate facial movements of anyone to whom they are applied. A lack of contouring or attention thus demarcates Smug's 'blackness' from that visible in professional and courtly theatrical spaces so that the carnivalesque reproduction of 'blackness' represented in The Merry Jests of Smug the Smith is crude and flat. 
Smug's blackened body is, in contrast to the plays I will now consider, comical in its crude stagecraft.

\section{Material Blackness in Early Modern Drama}

Titus Andronicus uses the materiality of early modern staged 'blackness' and its inherent potential for transferability as a vehicle for marking the imagined dangers of racial others. The play features bodies marked as other by skin read as both darker and lighter than that of the normative group of Romans; as Francesca Royster argues, audiences can read the bodies of Tamora and her sons as 'hyperwhite', resulting in the 'othering of a woman who is strikingly white'. ${ }^{26}$ The play marks Tamora, a 'Roman now adopted happily' (1.1.460), as sexually and morally degraded by her illicit proximity to Aaron the Moor but this imagining of discolouration takes place against the backdrop of a city preoccupied with colour and its movement. Tamora imagines that the sacrifice of Alarbus will 'stain .... thy tomb with blood' (116), but Titus has already 'marked' the Goth for sacrifice (125). Titus is subsequently offered a 'palliament of white and spotless hue' (182) to signify the emperorship. The image of blood as an agent for discolouration also features in Titus's response to the news of Quintus's and Martius's arrest - 'my sons' sweet blood will make [the earth] shame and blush' — in which the earth figures as a site of changing colour both from the spilt blood and in a blushing, shamed response to their deaths (3.1.15). Later, the play imagines the sun stained with fog in response to Titus's grief (211), and the tarnishing properties of blood are the last image of Titus for audiences as Lucius kisses and weeps upon his father's 'bloodstained face' (5.3.153). The teary face of Lavinia is 'stained, like meadows yet not dry, / With miry slime left on them by a flood', while the sight of her strikes Titus and Lucius 'pale and bloodless' (3.1.124-5, 256). Titus locates itself in a world of shifting colour, so that changes in colour mark emotional and bodily changes. Colour changing, and the materials used to change bodily colour, are embedded in the bodies of its characters.

When Bassianus and Lavinia find Tamora and Aaron together in a secluded clearing in 1.1, the play indicates the denigration of their relationship in terms of colour and its transference. It is Tamora's exceptionally pale skin that first draws the Emperor's attention; he proclaims that she is 'of the hue / That I would choose' as a bride, therefore rendering her an object of voyeuristic exoticism (261), and her comparative paleness to Lavinia means that Saturninus imagines her as a desirable other. Later, that hyperwhiteness and its relationship with Aaron's blackness is the focus of Bassianus and Lavinia's censure of Tamora's sexuality: 
Believe me, Queen, your swarthy Cimmerian

Doth make your honour of his body's hue,

Spotted, detestable, and abominable.

Why are you sequestered from all your train,

Dismounted from your snow-white goodly steed,

And wondered hither to an obscure plot,

Accompanied but with a barbarous Moor,

If foul desire had not conducted you?

Bassanius views Tamora as morally 'spotted, detestable, and abominable' by virtue of her proximity to a black racial other. Aaron's black body transforms her to 'his body's hue' and in Bassanius's mind she is now akin to that 'checkered shadow on the ground' under which she earlier attempted to entice Aaron to dally (15). The exterior blackness of the Moor now allegedly marks Tamora's interior whiteness, her honour, such that she appears, like Aaron, as a racial other rather that as part of the 'train' of fair Romans; Lavinia later imagines her as 'the blot and enemy' of womankind, thereby disavowing her participation in a white and fair femininity (183). Tamora's body localizes the potential for colour; Bassanius and Lavinia see her proximity to Aaron's black body as discolouring her hyperwhiteness.

The transfer of bodily colour in Titus, however, extends beyond black to white. The figuring of the Goths as a discrete racial group results in an imagined potential movement between their racially othered white skin and the white and fair skin of the Romans. Titus's speech condemning the brothers' act mirrors the language Bassianus uses in relation to Tamora:

$\mathrm{O}$ villains Chiron and Demetrius,

Here stands the spring whom you have stained with mud,

This godly summer with your winter mixed.

You killed her husband, and for that vile fault

Two of her brothers were condemned to death,

My hand cut off, and made a merry jest;

Both her sweet hands, her tongue, and that more dear

Than hands or tongue, her spotless chastity,

Inhuman traitors, you constrained and forced.

Much as the materials used in the recreation of blackness mark Aaron's body along with the language that describes that blackness, the material conditions of Chiron and Demetrius's hyperwhiteness are also visible in the text when Aaron refers to the pair as 'white-limed walls' (4.2.98). Like the alabaster calcine, azarum, starch, 
sulphur, powdered bone, ceruse, and arsenic that made up whitening cosmetics to cover less desirable complexions, quicklime covered the unseemly wattle and daub of walls; ${ }^{27}$ the rape of Lavinia has 'stained' and 'mixed' her bodily purity with this hyperwhite 'mud', and her formerly 'spotless chastity' has therefore been spotted by Chiron and Demetrius. The racially normative Roman body has been discoloured by their hyperwhiteness. In addition to the muddy staining of Chiron and Demetrius, Titus's speech evokes the bloody discolouration which stains the Andronici family and their tomb with the close verbal association of mud/blood. For the reader, this verbal slippage and description of Lavinia as a 'spring' re-establish her in the audience's imagination as Marcus describes her immediately after the attack: with 'a crimson river of warm blood, / Like to a bubbling fountain ... between thy rosèd lips ... As from a conduit with three issuing spouts' (2.4.22-30). If Lavinia is left in her bloody garments, in performance, the stained prosthetics embody the uneasy image which Titus presents of her as somehow morally and sexually 'discoloured'. In the same way that the play imagines Tamora as changed or spotted by her proximity to racial otherness, so too has Lavinia been marked. ${ }^{28}$

Potentially transferrable colour connects characters and racial groups within Titus. Tamora's representation as a woman marked by her deviant sexual proximity to a black man finds an uneasy parallel in the representation of Lavinia's forced sexual interaction with two hyperwhite men. The two women are not mirrored, but they do share signifiers and therefore elements of their representation overlap. The play uses the same terms of discolouration to describe the moral and sexual consequences of proximity to racial others whether the source of the fluid skin is blackness or hyperwhiteness. When plays imagine hyperwhiteness as being sexually or morally dangerous to the dominant racial group, it can be conflated with blackness. Titus's speech reconstructs a binary of them/us on a binary of other/ white. The inherent instability of the materials used in recreating blackness on the early modern stage means that blackness and its otherness can be co-opted to perform multiple discourses. The Goth men are 'mud' while Lavinia's body is a 'spring' open to their discolouring proximity. The suggestion that Lavinia has been 'discoloured', however, further complicates this binary. She has been 'stained' and her 'spotless chastity' has been destroyed by the rape; as it dwells on her previous uncompromised moral-aesthetic whiteness, Titus's speech constructs Lavinia as now being less than sexually and aesthetically pure. This same imagery appears in Bassianus's speech about Tamora's proximity to Aaron. The centring of this language of discolouration and transfer on the play's two female characters suggests that the female body is most susceptible to colour transfer and fluid 
identity. The female body in Titus does not have a fixed and stable identity, but one that can be changed by sexual proximity to the othered male body, whether that body is black or hyperwhite.

Awareness of the potential for the transfer of colour on the early modern stage informs representations of the potential shifting of pigmentation during performance. The movement of colour in relation to the female body is a signifier of moral disobedience to patriarchal values, particularly those governing sexual behaviour. Titus imagines this uncontrolled female sexuality as 'discolouration' on Tamora's hyperwhite body - a body which, through Chiron and Demetrius, discolours others - and is embodied on the stage as a baby, described as a 'joyless, dismal, black, and sorrowful issue' and 'as loathsome as a toad / Amongst the fair-faced breeders of our clime' $(4.2 .66,68)$. Tamora's black sexual interiority and Aaron's black racial exteriority mean that their offspring is born embodying the 'unnatural' relationship between black and (hyper)white - Aaron's 'seal [is] stamped in his face' (127). Although Tamora intends for Aaron to 'christen it with thy dagger's point', Aaron seizes the child and declares it to be 'my first born son and heir' $(70,92)$. He then reverses the idea of blackness as being fluid, arguing instead that it is a 'natural' and 'stable' skin colour rather than the hyperwhiteness of the Goths or the fairness of the Romans:

What, what, ye sanguine, shallow-hearted boys,

Ye white-limed walls, ye alehouse painted signs!

Coal-black is better than another hue;

In that it scorns to bear another hue;

For all the water in the ocean

Can never turn the swan's black legs to white,

Although she lave them hourly in the flood.

Why, there's the privilege your beauty bears.

Fie, treacherous hue, that will betray with blushing

The close enacts and counsels of thy heart!

Here's a young lad framed of another leer;

Look how the black slave smiles upon the father,

As who should say, 'Old lad, I am thine own'.

$\mathrm{He}$ is your brother, lords, sensibly fed

Of that self blood that first gave life to you,

And from that womb where you imprisoned were

He is enfranchisèd and come to light. 
Nay, he is your brother by the surer side,

Although my seal be stampèd in his face.

(97-103, 116-27)

Aaron imagines the whiteness of the Goths as paint that water can wash away. Aaron figures the Goths' whiteness as a temporary addition to another 'natural' colour. ${ }^{29}$ This passage constructs natural blackness as superior both in its perceived inability to 'betray' the body by blushing and in its ability to propagate itself; Aaron and his speech embody contemporary concerns around 'miscegenation' as being dangerous to Caucasian-centric communities in its potential to overpower whiteness. Another biracial baby born in Titus to Muliteus, a Moor, and his Roman (fair) wife, however, embodies a second danger of miscegenation. This child is as 'fair to [the mother], as fair as [Chiron and Demetrius] are' and is therefore a potential site of unreadable blackness. As Annette Drew-Bear notes, these children show 'the potential for a growing network of "others", working together in possibly subversive ways, marrying white wives, having children who may pass for white. ${ }^{30}$ In Titus, the fluid sexual bodies of women enable this subversive network: women who are externally marked by their proximity to cosmetic costumes recreate racial others and then subsequently produce racially unreadable offspring. As the materials used in the recreation of 'blackness' are transferrable to 'white' bodies, so too is blackness imagined as being easily and dangerously moveable from generation to generation via 'white' wombs.

The material reconstruction of blackness in Heminges's The Fatal Contract (1653) further embodies sex and its potential for racial, sexual, and moral movement. This play imagines sexual relationships as a site of potential colour transfer, and familial and female 'discolouration' becomes a violent threat. Heminges's plot revolves around the machinations of an early French monarchy in which the queen, Fredigond, through her faithful Moorish eunuch, Castrato, seeks revenge for Chrotilda's family's murder of Fredigond's brother Clodimer. Chrotilda, a noblewoman and sister to Lamot and Dumain, has been raped by Clotair, Fredigond's son, and vanishes, assumed dead. Vowing loyalty to the queen, Castrato claims that he would 'search the Deserts, Mountaines, Vallies, Plaines' for Chrotilda, whom he would then'make to mingle with these sootie limbs' so that he 'got on her one like to me', thereby haunting her family line with a 'Devil' as a 'Grand-father' (1.2.57-63). ${ }^{31}$ The play ends, however, with the deathbed revelation that Castrato is Chrotilda, and that s/he has poisoned Fredigond. In 1.2, the threat which Chrotilda makes against herself while disguised as Castrato is threefold: Chrotilda will be raped and her white body discoloured by her rapist's 'sootie' limbs; her pregnancy will evidence their sexual activity; and the eunuch's 
devilry (here figured as his imagined blackness) will become an indelible part of her line as on ongoing mark of his violation of Chrotilda. The threat builds upon the eunuch's blackness and its potential to mark both Chrotilda and, through her, an entire family. From its earliest moments, when Chrotilda's brothers complain of 'bruised Arms', the play imagines this discolouration of her family (1.1.6). Castrato's threat of marking and raping Chrotilda for the queen is imagined by the diabolical pair as a threat worst and more profound than the rape which has already been enacted on Chrotilda by Clotair. The Fatal Contract imagines the violent begetting of 'black and sorrowful issue' on a white woman to be worse than the violence and social ostracization that was the result of Chrotilda's rape (Titus 4.2.66).

The eunuch's threat, however, is complicated by the play's revelation of his 'true' identity as Chrotilda herself, in a twist which is as surprising to the other characters as it is to the audience. Unusually, there are no asides, demonstrations, or clues that the Eunuch is not who 'he' seems to be, other than his seemingly excessive hatred of the royal family. For later audiences and readers, this knowledge has a profound impact on readings of this moment. Chrotilda is imagining the violence of rape, pregnancy, and family breakdown working on her own body, a body which has already suffered violent rape and social ostracization. The mingling of her arms and the eunuch's arms has already occurred through the material blackening of Crotilda's European whiteness - the eunuch/Chrotilda makes this threat knowing that 'she' has already been comprehensively blackened. Chrotilda's arms have been completely mingled with the Eunuch's 'sootie' ones; she has marked her body with his imagined body. For Carol Ann Morley, Chrotilda's 'outward blackness embodies the evil of the rape she has suffered, her "castration", the irreversible sexual damage done to her. ${ }^{32}$ She chooses this mode of disguise, then, to match her exteriority with her interiority. Thus the eunuch/Chrotilda's avowal to have 'his face [as] black [as] he'l [sic] have his soul' is embodied in the eunuch/Chrotilda's body as 'she' becomes as physically dark as her revenge plot is metaphorically black (2.2.33).

The Fatal Contract lacks the metatheatrical references to the materials or problems of the recreation of blackness on the early modern stage that we see in Titus. Other than the eunuch's 'sootie' arms, no other reference to the prosthetic blackness of the early modern stage exists. Heminges's suppression of the material facts of 'blackness' in his play works to discourage any audience suspicion that the eunuch may be using blackness as a disguise; just as the change of title from The Eunuch to The Fatal Contract elides the presence of the eunuch and the importance of the role, ${ }^{33}$ so too does suppressing the material conditions with which the 
actors and Chrotilda create the character counter any suspicion that Castrato is in disguise.

Heminges uses the audience's awareness of the problems of materially creating blackness to further hide the eunuch's disguise. The assumption of the creation of blackness on the stage thus obscures the creation and recreation of blackness in the play. Despite the eunuch's proximity to other characters - a little after threatening to sexually 'discolour' Chrotilda and her family, 'he' kisses the queen twice, and spends a significant amount of the play in corners with people spying - the text makes no implicit or explicit acknowledgement of any transfer of colour, nor does it show any concern over the potential for colour transfer (1.2.91-5). In the only other reference to changing colours in the play, Clotair announces that he will marry Aphelia at her betrothed's funeral: 'Turn all your sables to the Tyrian dye, / Your dirges into sprightful wedding airs' (3.3.67-8). Blackness changes both metaphorically (from funeral to wedding colours) and materially (with dye). Between local bodies colour is not textually imagined as being transferrable. That does not mean, however, that the materials used in the recreation of the eunuch's blackness were not slipping, or that this slippage was not a concern - as demonstrated earlier, contemporaries perceived the material conditions of 'blackness' on the seventeenth-century stage as highly unstable. Heminges's lack of recognition of this potential for movement (actual or imagined) relies on the audience expecting and overlooking any possible transfer of colour. The moments in which Chrotilda's disguise would or could be visible through a metatheatrical awareness of disguise and bodily change are explained away by the audience because of their recognition of the potential slippage inherent in the materials used to recreate the eunuch's blackness. The recreation of the eunuch's body as a racial other hides the recreation of a disguised Chrotilda/eunuch. For the audience, the reconstruction of the racially othered body of the eunuch can explain any movement of the eunuch/Chrotilda's 'blackness'. The audience does not see the disguise because the audience is already reading that body as being 'transformed' from 'white' to 'black'. Heminges depends on audience awareness of the material problems inherent in the recreation of 'blackness' on the seventeenth-century stage to explain and therefore enable audience awareness of the moral and political 'blackness' of the French court portrayed in The Fatal Contract.

Settle adapted The Fatal Contract in 1675. His adaptation, Love and Revenge, does not differ substantially from Heminges's play, although it makes the materiality of blackness visible to the audience both more quickly and more comprehensively. The eunuch character, Nigrello, is revealed as disguised within the first act, although the extent of his disguise as Chlotilda is not realized until the final 
act when 'he' 'turn[s] Woman / in the last action of my Life' (5.1.1311-12). ${ }^{34}$ Clotair initially reads Nigrello's disguise in terms of its blackness and the perceived incongruity between blackness and 'noble' revenge: 'by thy glorious Villainy, thy Wit, / Thy courage, and thy Conduct, I am sure / That blackness hides some noble blood' (5.1.325-7). Revenge is the prerogative of white bodies in Love and Revenge; partaking in patterns of behaviour normatively read in the dominant racial group subjugates the 'black' body and reveals it to be a disguise.

The Epilogue, which appears before the character list in the printed editions of the play, further asserts Nigrello/Chlotilda's 'white' and 'female' body over the 'black' male-sexed body with which he/she has been disguised throughout the play. The Epilogue is 'spoken by Nigrello in a Mans [sic] Habit, but in a white Wig, and her Face discover'd' (A6r); 35 the actress who is playing Nigrello/Chlotilda wears a variety of costumes signalling a mix of gender and racial identities, including the masculine costume of Nigrello, a partial covering of those black cosmetics which signify racial otherness, and a post-play 'white wig' (presumably a European style with powdered hair) to signal the feminine body of the actress. Therefore, costumes simultaneously signal the body of Nigrello/Chlotilda as being black, white, female, and male. At this moment the text supports the white wig as the primary costume, with the female pronoun used both in the directions and in Nigrello/Chlotilda's speech. Chlotilda's female-sexed white body is revealed onstage with no time for any costume changes. Thus the strongest costume signal of the Epilogue is one which does not appear on stage during the play proper. Of course, Revenge was performed with a female actor in the role of Chlotilda; the disguising of Chlotilda as Nigrello and the inherent potential for colour transfer is made even more dangerous when enacted on a white female body, without the safety of metatheatrical glances to the boy actor's body. It then becomes of great importance to signal the material reconstruction and the ease of removal of the staged body, and to strip it back to its 'true' identity.

This paper has demonstrated that the visibility of the materials used in the reproduction of blackness on the seventeenth-century stage intertwines with dialogues recreating blackness as being dangerously fluid. The potential for transfer inherent in easily accessible and cheap materials such as soot and coal mimics their use in rhetoric to carry or enhance notions of race as connected with devilry, miscegenation, threat, and dangerously shifting identity. Reading Carleton's and Booth's accounts of imagined and realized material transfer at either end of the century throws into sharp relief the material practices of the recreation of blackness on the seventeenth-century stage. In Titus Andronicus, The Fatal Contract, and Love and Revenge, such material practices inform and are informed by ideas of 
race, so that the materials used to recreate blackness on the seventeenth-century stage are bound up in early modern English representations of race beyond the stage. In the plays considered here, the material components used in the creation of blackening cosmetic prosthetics connect to discourses of unstable racial identity present in early modern drama. The material conditions of blackness on the seventeenth-century stage therefore contribute to contemporary fears of racial contamination and perceived threats to early modern English identity and nationhood, demonstrating the profound impact which material studies can have on understandings of the history of race and on the processes by which racism and exclusion are embedded in language.

\section{Notes}

This article and its author owe a great debt to Chloë Houston, Mark Hutchings, Michelle O'Callaghan, Alison Findlay, Christine Carr, the two diligent and generous anonymous reviewers at Early Theatre, and Clare McManus. Research was supported by the Arts and Humanities Research Council and the University of Reading through an AHRC PhD Studentship.

1 For the text of Carleton's letter, see David Bevington, Martin Butler, and Ian Donaldson (eds), The Cambridge Edition of the Works of Ben Jonson, 7 vols (Cambridge, 2012). 1.448-9, http://dx.doi.org/10.3366/bjj.2013.0086. All subsequent quotations from Carleton's letter and from the Masque of Blackness will be taken from this edition. A significant body of work exists around this performance of The Masque of Blackness and the letters. See Hardin Aasand, "To Blanch an Ethiop, and Revive a Corse": Queen Anne and The Masque of Blackness', SEL Studies in English Literature 1500-1900 32.2 (1992), 271-85, http://dx.doi.org/10.2307/450736; Clare McManus, Women on the Renaissance Stage: Anna of Denmark and Female Masquing in the Stuart Court (1590-1619) (Manchester, 2002), http://dx.doi. org/10.1017/s0307883303280172; Sujata Iyengar, Shades of Difference: Mythologies of Skin Colour in Early Modern England (Pennsylvania, 2011), 90-100, http://dx.doi. org/10.9783/9780812202335.

2 Michael Neill (ed.), The Oxford Shakespeare: Othello (Oxford, 2006), http://dx.doi. org/10.1093/actrade/9780198129202.book.1.

3 The use of 'miscegenation' in relation to early modern texts is problematic, as this term was not yet in use. See Kim Hall, Things of Darkness: Economies of Race and Gender in Early Modern England (Ithaca, 1995), 160-76. 
4 Ian Smith, 'Barbarian Errors: Performing Race in Early Modern England', Shakespeare Quarterly 49 (1998), 181, http://dx.doi.org/10.2307/2902299.

5 Ibid, 181.

6 R.K.R. Thornton and T.G.S. Cain (eds), A Treatise Concerning the Arte of Limning (Ashington, 1981), 91.

7 Meg Twycross and Sarah Carpenter, Masks and Masking in Medieval and Early Tudor England (Aldershot, 2002), 316, 311-26.

8 Farah Karim-Cooper, Cosmetics in Shakespearean and Renaissance Drama (Edinburgh, 2006), http://dx.doi.org/10.3366/edinburgh/97807486619931.001.0001.

9 Ibid, 317, 327-32. The contouring would not, of course, give a 'natural' look to the wearer but, as Twycross and Carpenter note, the equation of cosmetics with masks in discourses surrounding 'painting' undermines any modern assumption that cosmetic use either in or out of theatres would be naturalistic. Nevertheless, some limited contouring would allow a performer a wider range of facial expression.

10 Philip H. Highfill Jr, Kalman A. Burnim, and Edward A. Langhans, A Biographical Dictionary of Actors, Actresses, Musicians, Dancers, Managers and Other Stage Personnel in London 1680-1800, 16 vols (Carbondale, 1973-93), 1.211-12.

11 This potential for slippage continued to be problematic long after the period with which this article is concerned: in 1848, John Coleman was horrified to leave dark handprints on the white cashmere robe worn by William Macready as Iago, and, in the 1965 Laurence Olivier performance, Maggie Smith's Desdemona was marked by Olivier's stage makeup. Lois Potter, Othello: Shakespeare in Performance (Manchester, 2002), 29-31.

12 Eugene Waith (ed.), Titus Andronicus (Oxford, 1984), http://dx.doi.org/10.1093/ actrade/9780198129028.book.1.

13 Bevington et al. (eds), Ben Jonson, 4.327. In this moment we also see the intersection of race-related and aesthetic-related cosmetics: the actor performing Vulcan has used both a 'sooty' blackening cosmetic and the egg-wash used to give a desirable European lustre to 'his' face.

14 Gervase Markham, The Dumb Knight: A Historical Comedy (London, 1608; sтC: 17398).

15 Bevington et al. (eds), Ben Jonson, vol. 7.

16 Thomas Middleton, William Rowley, and Edgar Cait Morris, The Spanish Gipsie, and All's Lost by Lust (London, 1908).

17 I.G. Gent, The Strange Discovery: A Tragi-Comedy (London, 1640; sтc: 12133). See also William Gouge, The Saints Sacrifice (London, 1632; sTC: 12125). 
18 Andrea Stevens, Inventions of the Skin: The Painted Body in Early English Drama 1400-1642 (Edinburgh, 2013), 88, http://dx.doi.org/10.3366/edinburgh /9780748670499.001.0001.

19 Dympna Callaghan, Shakespeare Without Women (London, 2002), 76, http://dx.doi. org/10.4324/9780203457726.

20 For work on hands, see Farah Karim-Cooper, The Hand on the Shakespearean Stage (London, 2016), 157-96, http://dx.doi.org/10.3366/edinburgh 19780748619931.001.0001, in which she argues for the importance of touch in Othello, and reads Iago as ultimately subverting the use and rhetoric of touch to destroy Othello and Desdemona.

21 Stevens, Inventions, 9-10. See Andrea Stevens, 'Mastering Masques of Blackness: Jonson's Masque of Blackness, the Windsor Text of The Gypsies Metamorphosed, and Brome's The English Moor', ELR 39.2 (2009), 396-426, http://dx.doi.org/10.1111/ j.1475-6757.2009.01052.x.

22 Ian Smith, 'Othello's Black Handkerchief', Shakespeare Quarterly 64.1 (2013), 12, http://dx.doi.org/10.1353/shq.2013.0017. See also his Race and Rhetoric in the Renaissance (Basingstoke, 2009), http://dx.doi.org/10.1057/9780230102064.

23 T.B., The Merry Jests of Smug the Smith, or, the Life and Death of the Merry Divel of Edmonton (London, 1657; sTC: 4431). The story of Smug has many hallmarks of a theatrical performance: a character is made into someone he is not and attracts the attention of a rowdy audience, and his performance is even subsequently committed to the printing press, to be disseminated to a reading audience.

24 This performance can be read as a form of mumming following Herbert Halpert's typology - it is an informal or general outdoor mumming, of the type that Twycross and Carpenter identify as being popular in Britain during the fourteenth to seventeenth centuries (Masks and Masking, 84).

25 Ibid, 82-5.

26 Francesca T. Royster, 'White-Limed Walls: Whiteness and Gothic Extremism in Shakespeare's Titus Andronicus', Shakespeare Quarterly 51.4 (2000), 432, http:// dx.doi.org/10.2307/2902338. 'Hyperwhite' is borrowed from Royster throughout.

27 For work on the creation of cosmetics, see N. Williams, Powder and Paint: A History of the Englishwoman's Toilet (London, 1975) 172-216; M. Angeloglou, A History of Make-Up (London, 1970). For work on cosmetics, gender, and the theatre, see KarimCooper, Cosmetics; Tanya Pollard, Drugs and Theatre in Early Modern England (Oxford, 2005), http://dx.doi.org/10.1093/acprof:oso/9780199270835.001.0001.

28 For the purpose of this article, I do not draw distinctions between the sexual activities performed by/on Tamora and Lavinia. The similarity in the depiction of Tamora and Lavinia raises questions about depictions of consensual and 
non-consensual sex in the play and beyond that exceed the scope of this article. For work on early modern representations of rape, see Jocelyn Catty, Writing Rape, Writing Women in Early Modern England: Unbridled Speech (London, 2010), http:// dx.doi.org/10.1057/9780230309074; Garthine Walker, 'Rereading Rape and Sexual Violence in Early Modern England', Gender \& History 10.1 (1998), 1-25, http:// dx.doi.org/10.1111/1468-0424.00087; Frances Dolan, 'Re-reading Rape in The Changeling', Journal for Early Modern Cultural Studies 11.1 (2011), 4-29, http:// dx.doi.org/10.1353/jem.2011.0014.

29 The removable whiteness portrayed by Aaron also connects it to cosmetic practices in the recreation of women. See Karim-Cooper, Cosmetics, 1-14.

30 Annette Drew-Bear, Painted Faces on the Renaissance Stage: The Moral Significance of Face-Painting Conventions (London, 1994), 93. This 'network of "others"' was located within a wider group of 'racial others' within London. Peter Fryer finds that from the 1650s onwards there was a rapid jump in the number of black people in London as a result of the increasing demand for sugar and an increasingly regularized slave trade to meet that demand, and Imitiaz Habib's extensive survey of black people in royal, legal, and parish records from 1500-1677 concludes that 'black people are a pervasive, repetitive, and accelerating presence in Elizabethan London, and therefore a part of the city's collective social consciousness'. Peter Fryer, Staying Power: The History of Black People in Britain (London, 1984), 8; Imitiaz Habib, Black Lives in the English Archives, 1500-1677: Imprints of the Invisible (Aldershot, 2008), 116.

31 Carol Morley (ed.), The Plays and Poems of William Heminges (Madison, 2006).

32 Ibid, 287.

33 Ibid, 17-32.

34 Elkanah Settle, Love and Revenge: A Tragedy in Five Acts (London, 1675; Wing: S2698) (rpt London, 2010).

35 'Discover'd' may refer to the use of a mask to recreate blackness, which Nigrello then removes to expose Chlotilda; the text, however, does not contain any stage direction to support this supposition. Instead, Chlotilda declares that 'I put on my own Sex agen to dye' without any reference from either herself or any other character to removing a mask or in any way supplanting Nigrello's blackness with Chlotilda's whiteness (5.1.346). Indeed, repeated assertions from other characters enforce the idea that the body of Nigrello is to be read as that of Chlotilda, rather than relying on a visual signifier of that swap. 
